\title{
THE INFLUENCE OF TSUNAMI RELOCATED HOUSING ON THE CHANGES IN THE ACEH COASTAL MOUNTAIN NATURE AND IMPACT ON ECONOMIC ACTIVITIES OF LOCAL COMMUNITIES
}

\author{
Elysa Wulandari', Zahriah ${ }^{2}$, Zahrul Fuadi ${ }^{3}$, Farisa Sabila ${ }^{4}$ \\ 1,2,3,4 Program Studi Perencanaan Wilayah dan Kota, Fakultas Teknik, Universitas Syiah Kuala, \\ Banda Aceh \\ Corresponding Author: elysa wulandari@unsyiah.ac.id \\ Received: 29 Oktober \\ 2020 \\ Revised: 3 November \\ 2020 \\ Article History: \\ Accepted: 14 December Available online: 18 December \\ 2020 \\ 2020
}

\begin{abstract}
This paper reveals how the land use change process occurred due to the construction of post-tsunami relocation housing environments, and its impact on the pattern of daily economic activities of local communities in the coastal hilly areas. This study is important along with UU no. 24 Tahun 2007 concerning disaster management that disaster reconstruction activities must take into account the character of the local community and environmental sustainability. The phenomenological approach in this study is by observing the symptoms of the interaction between the artificial environment of the estate settlement, rural environment, and local residentsimmigrants and the impact of the system's sustainability in the region. The data such as: 1) pretsunami and current land use maps (2020); 2) observation data, regarding daily activities of economic activities in the area; 3 ) interviews with community leaders to explain the dynamics of local people's economic activities. The analysis method uses a manual interaction diagram system, to read the causality structure which analyzed with "logic of space". The results are: a) the location of relocated housing has shifted the location of livestock grazing and agricultural gardens towards hills as well as developing mining business activities $C$ about $0.5-1 \mathrm{Km}$ from the housing, which is at risk of natural hazards; $b$ ) the housing environment somehow hinders the people's daily freedom of movement and livestock towards the hills. Livestock sometimes cross residential areas and even eat plants in house yards and green open spaces and these disturb the comfort of residential residents. The conclusion is that the pattern of placing the relocated housing environment has created "space in space" which changes the pattern of community home-range activities. Suggestions for the sustainability of the economic life of local residents and the comfort of living for newcomers are the need for a strategy to organize an official route of movement to the hills and to make improvements to land for the hills, as well as the obligation to permanently fence off the housing environment. Both things are done with systems approach and synergize the interests of local communities and migrant communities.
\end{abstract}

Keywords - relocated housing, vernacular settlements, hilly coastal areas, spatial behavior, Aceh Besar

\section{Introduction}

The 2004 Aceh tsunami, the biggest disaster in the world in the 21st century, has changed the structure of the community's living space and the natural environment in the coastal areas of Aceh, even eliminating the great civilization of Aceh that originated in the XVII century such as the city of Banda Aceh (Wulandari, 2017). The traditional coastal communities of Aceh are actually very familiar with various disasters, they survive in various ways, such as relocating villages gradually (Wulandari, et al, 2020a). In the 2004 tsunami incident, various attempts were made to reconstruct the impact of the disaster, among others, the construction of relocation housing by the government and non-governmental organizations, both from within and from abroad (Annual 
Report 2007 BRR NAD-Nias, 2008).The construction of relocation housing for the affected communities in several places appears to have caused dynamics in the relocation area, both in terms of living and land use patterns around it (Wulandari et al., 2020b).

The Neuheun area is located on the north coast of Aceh Besar Regency and is at the foot of the hills of Ujung Batee which is one of the areas where housing for the victims of the tsunami disaster in Aceh have relocated 7 relocation houses (informant Faizan). The shape of the residential neighborhood extends parallel to the foot of the hills with various environmental patterns. However, every housing has a ring road on its outskirts that limits the housing environment and the outer housing environment, which is the hilly area. Take a look at the figure:

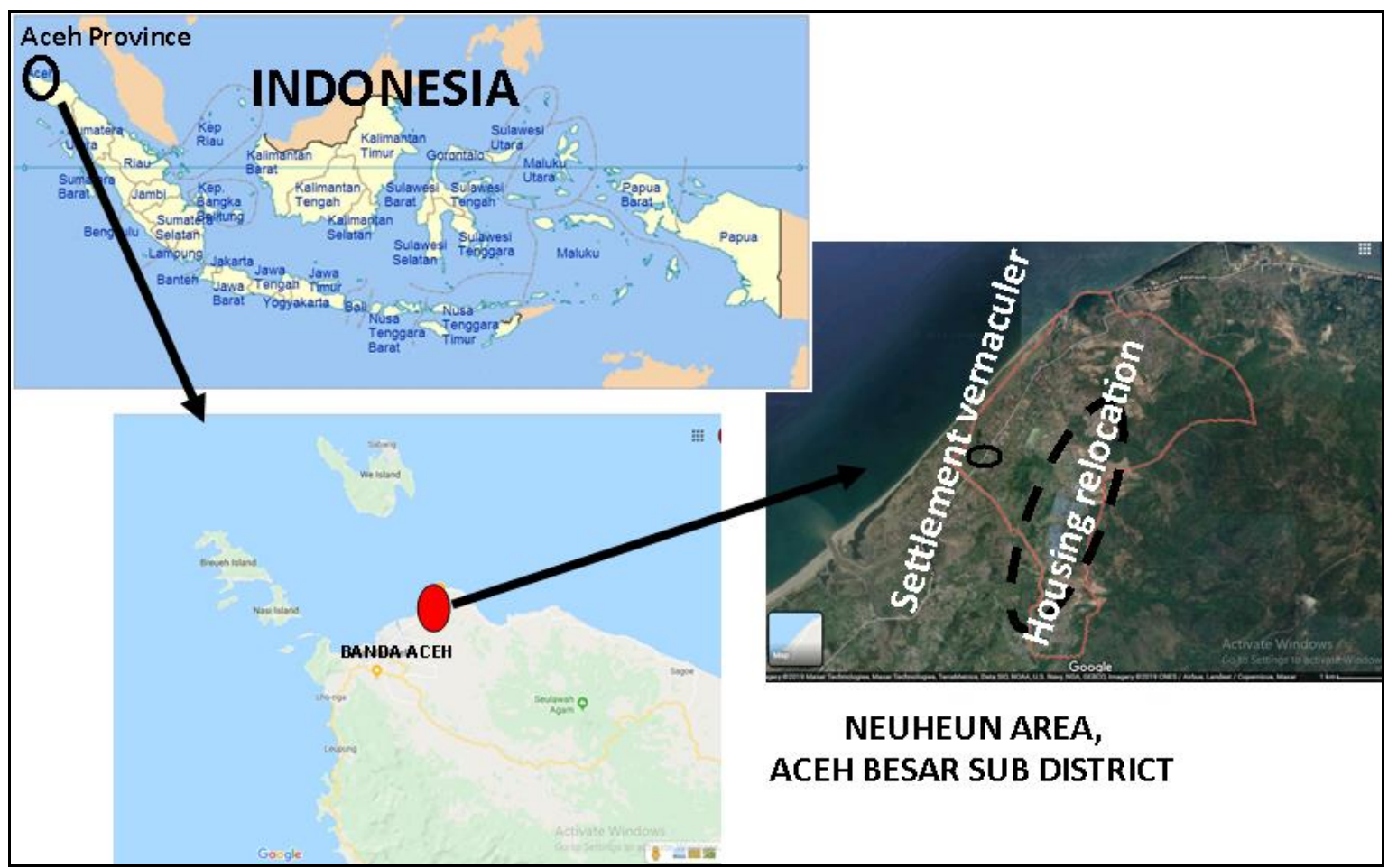

Figure 1: The Map of The Location and The Form of the Housing Environment, 2020, Photo. Source: Google.

The Relocation Housing was built by various donors by buying local residents' land which was previously designated for grazing land, agricultural gardens, and places to collect fuel and so on. Relocation housing development started from the end of 2005 until 2007.

The local community of Gampong Neuheun is a rural community on the coast that has various livelihoods both on land and in water (informant: Faizan). The community carries out these economic activities on a daily basis which form a pattern of routine activities and become part of the community's socio-economic and cultural activities. If it is related to the theory of the relationship between the natural environment and the behavior of community spaces according to (Porteus, 1977), the pattern of economic activity in the community is categorized as a level of space that is macro space which is called the home range. Home range is a space outside of the home base, which physically cannot be fully controlled. The home range is generally for economic and social activities. In a land-based vernacular village, the character of the home range area will influence the character of the community. The character of the community is integrated with the natural system so that local wisdom is created (Keraf, 2014).

Repetitive spatial behavior within an area will form a fixed route. The route is formed based on the concept of logic of space, which is related between distance and time (Hillier and Janson, 1984). When there are obstacles in the movement route, there will be readjustment of the existing route as a form of adaptation. This adaptation pattern will affect the activity patterns of the local community and the conditions of the existing area. Therefore, if there is a change in systems in nature it will have an impact on the behavior in the home range area and its movement routes. Changes in land use for relocated housing in hilly areas as the home range of local communities 
will more or less affect the livelihoods of local residents and change the activity patterns and behavior of residents' spaces.

According to Alberti and Maezluff (Alberti, 2008), changes in a place always have a driving factor and will have various impacts on the systems contained in that place. Human ability to survive will appear to be a new spatial arrangement of an environment. The construction of relocation housing as a form of new land use that is present in the natural system of Neuheu hills will affect the spatial structure of the old area and will have an impact on the sustainable life system of the area, especially the activity patterns in the hills as a home range area.

Based on the above, this study aims to explain the phenomenon of the process of changing land use in hills due to relocated housing and changes in daily activity patterns and the behavior of local residents in hilly areas as the home range area. The research approach using phenomenological research is a way of understanding visible symptoms to see interactivity between humans and their natural environment (Schulz, 1984).

This research is important to do to evaluate the impact of post-disaster relocated housing development on the local community, so that it becomes a consideration for further planning. This is in accordance with UU no. 24 Tahun 2007 concerning disaster management and strengthened by Regulation of the Minister of Public Housing of the Republic of Indonesia No. 10 Tahun 2014 concerning guidelines for Natural Disaster Mitigation in the field of Housing and residential areas that post-disaster planning needs to pay attention to the sustainability of the lives of disaster victims and communities around the relocated location.

\section{Research Method}

This study uses a territorial research approach with process analysis (Yunus, 2010) and spatial trends whose impacts are analyzed using the manual dynamic system method, to see the cause and effect of a process so that problems can be identified in the process and can be controlled directly to the goals that we want. Validation is carried out in a feedback structure that shows the presence or absence of influence and the logic of influence. The time dimensions for the study is before the tsunami (2002) and after 10 years of relocated housing development (2020).

The research data consists of two types: a) Area spatial structure data was taken using satellite imagery maps from Google which are then delineated using space, then compared between the two times. The data were analyzed to see the difference in the image of the two maps which illustrates the dynamic process of the spatial structure of the Neuheun area. b) Process data on changes in spatial structure and land use that have an impact on local residents' home environmental activities. This data is obtained through interviews with community leaders who are depicted in a dynamic diagram system, so that development trends can be estimated.

\section{Result And Discussion}

\section{The Neuheun area as vernacular settlement}

The Neuheun area is a hilly coastal rural area that has a history as a land-based vernacular village from coastal to hilly areas. The center of the old Neuheun Village is near the mouth of a river-swamp at the foot of the hills, where the history of the community's existence is a migration from several places around the North coast of Aceh Besar after the independence era. While the history of the ancient origins of the location of the present Neuheun village, it is estimated that people lived during the kingdom of Aceh as seen from the many old graves and the presence of ancient wells. However, the existence of traces of the kingdom has been lost, it is estimated that it was destroyed by an ancient tsunami disaster, such as the 2004 tsunami which also damaged coastal villages.

In landscape, the area can be divided into four types of land forms: a) coastal and swamp areas used for ponds; b) low-sloping land areas as rice fields, housing, agriculture and types of business; c) the area of the foot hills for livestock pens and pasture; d) hilly area for gardens and a place to find wood. Take a look at the figure 


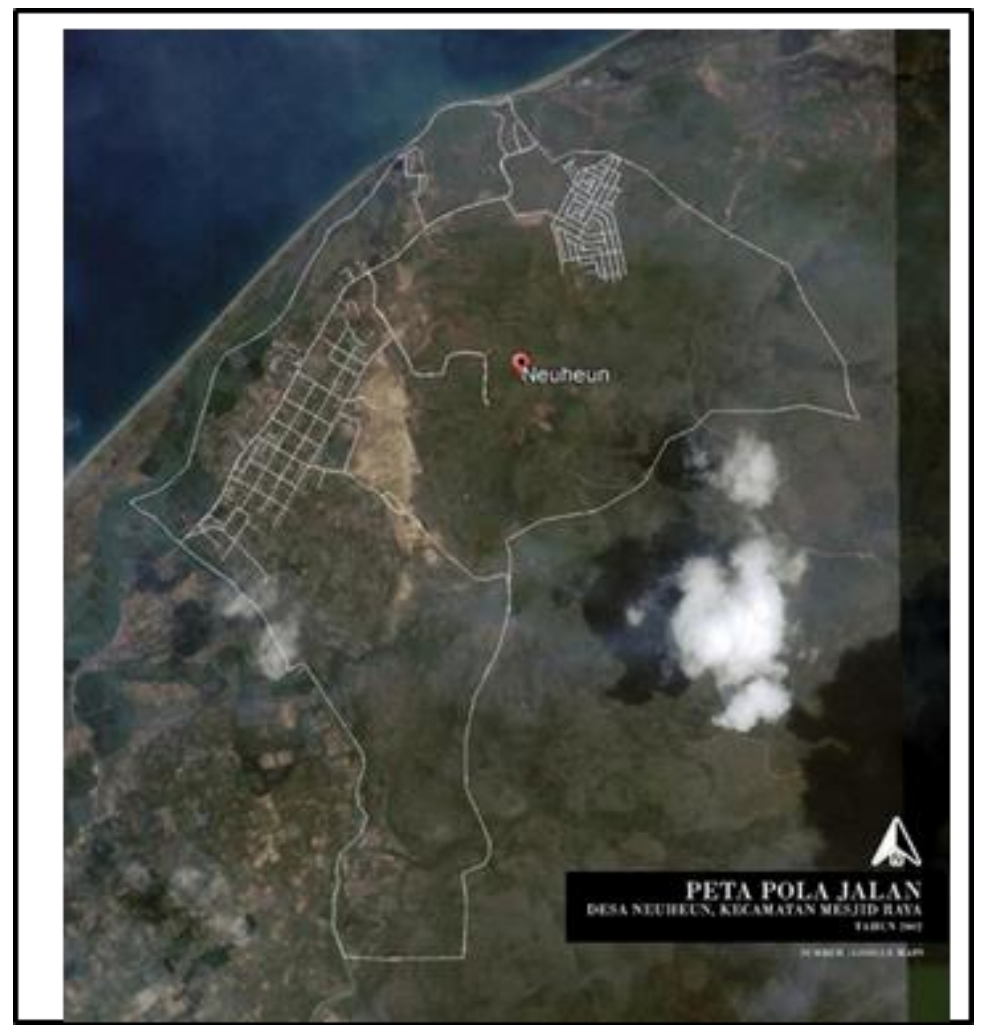

Figure 2: Map Orientation and Geographical Zonation, 2020, Photo. Source: Google map and analysis.

Diverse geographic conditions give rise to various forms of land-based community economic activities, which are: fishing, farming, gardening, livestock, mountain stone business, and other brick-and-mortar businesses. The hilly area is relatively more stable and safe from natural disasters compared to other areas in the Neuheun village area, so that people's lives as breeders and herders appear more stable. In contrast to their activities as fishermen and farmers, which are relatively unstable depending on the season. According to the Head of Neuheun Village, Neuheun Villagers do not like farming. However, it appears that businesses that grow consistently are those in the hills, especially as breeders.

\section{The Dynamics of Hill Land Use before the tsunami}

Land use in the Neuheun hilly area is also thought to have a long history related to the history of authority that had occurred in Aceh since the kingdom of Aceh to the Dutch colonial period. In the Neuheun area, there is a defensive fort as one of the locations for the defense fortress of the Acehnese kingdom which was part of the estuary of the Lambada Lhok river known as Kuala Gigieng. Therefore, it is estimated that the Neuheun hilly area was very strategic for surveillance to the sea when the kingdom of Aceh was an international maritime country in the 17th century (Wulandari, 2017), espesially the view towards the Northwest side of the bay of Aceh from the Andaman Ocean through the gaps of the islands. This strategic place was then continued by the Dutch and Japanese colonial period by building hilly fortresses, also on the coast.

During the Dutch colonial period, some of the hilly land became exploitable land (plantations) managed by the Bugis, Chinese, and Indians / Bengalis. Based on information from Harun Ahmad (a Neuheun resident), after independence until the 1980s, Neuheun hilly plantation land was abandoned and became a place for people to look for firewood sold at brick factories in Baitussalam sub-district, and take stones for building materials.

In the 1980s, the Aceh Besar district government cheaply sold the plantation land by plots of $25 \times 45$ sqm to communities in three villages, Lamnga, Kampung Baru and Neuheun. Therefore, the ownership of Neuheun hilly plantation land is not all owned by the Neuheun community so it is easy to buy and sell land for people outside Neuheun. 
The community uses the land for agriculture and livestock, especially cow, buffalo, goats and sheep. Therefore, male cows are kept in the garden, while female cows are left free whose grazing areas take advantage of hilly slopes and in hills. The daily activity pattern of livestock is when the cattle are released in the morning and will go to the hill as far as $5-10 \mathrm{~km}$, in the afternoon the cattle will return to the pen. According to the information from Harun Ahmad, there are 10 trails leading to the hills that can penetrate the South as far as $20 \mathrm{~km}$ to the Blang Bintang area (near the Aceh International Airport). The community usually controls the cattle to the hills 3-4 times during the day. Formerly done by walking, now sometimes by two-wheeled motorized vehicles.

The behavior of livestock that walks in the morning and evening often walks while eating plants around the route to the hill. Therefore, the community makes a local policy regarding the existence of livestock, agriculture and the home environment that every house and garden land must be fenced to avoid entering livestock. An exception is made for bad cows, the cows must be tied up. Fences are made from local plants (Indonesian: Kuda-Kuda, Acehnese: Geuruendong), which are up to 3-4 meters high, these plants turn the area green. The road space that has been formed has a clear character that distinguishes between the road space and the surrounding space, even in some places the land is tightly fenced. Thus, the road space has formed a regional spatial structure. See the figure below:

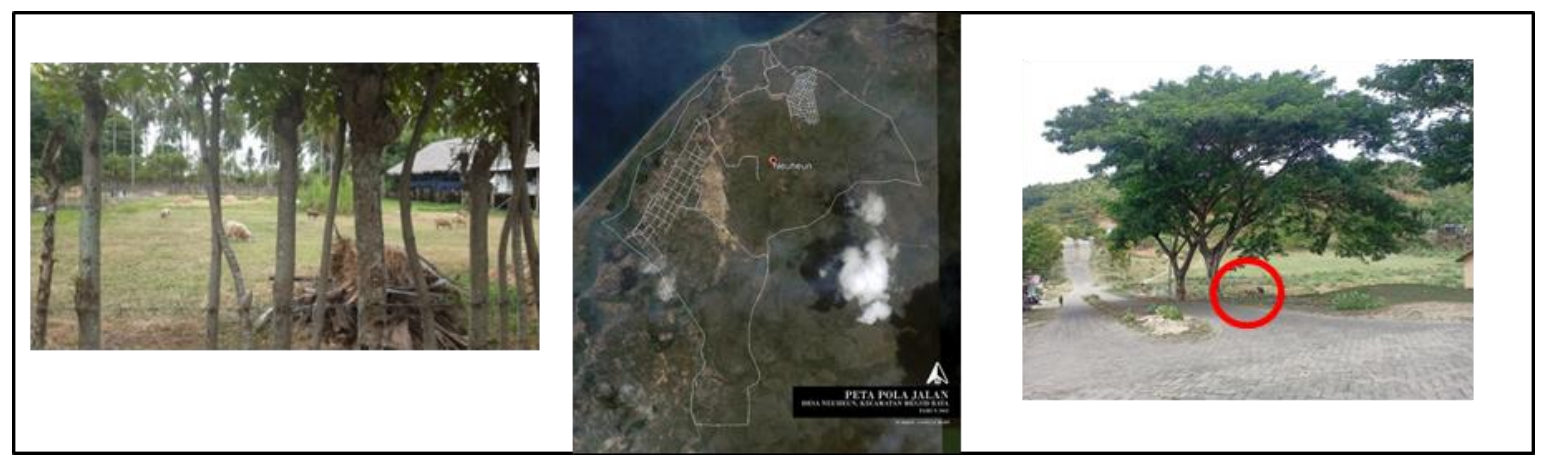

Figure 3: The locations of the cattle sheds and pasture land which is currently a relocated housing environment, 2020, photo. Source: Google and analysis

In one of the grazing fields there is only one channel, in the rainy season the water from the mountains will flow through the channel to the river. The water is often overflowed and usually the community will move livestock to the hills (information: The Head of Neuheun Village, 2020). The pattern of livestock movement appears to have formed places of economic activity in the hilly communities, both from places of stables, grazing areas and movement paths.

From the pattern of people's daily economic activities to the hills, it appears that the area already has an integrated environmental system between the existing residential and natural systems so that the daily life space of the community is integrated with the existing system in nature. This illustrates that the Neuheun Village area is a vernacular settlement. According to the definition of Schulz (1984), a vernacular settlement is a place of residence that develops in accordance with the character of the place. This will create a harmonious "space in space" concept between residential space and natural space. Based on the phenomenon of people's daily economic activities mentioned above, it appears that the spirit of place of the community is relatively high. According to Schulz (1984) the spirit of place forms the character of a spectacular settlement because of the totality of human relations with the place. The community fully orientates its life on that place and gives identity to that place, so that it can be distinguished from one place to another in an area.

\section{Impact of Relocated Housing on Systems in the Neuheun Area}

After the Tsunami, the pasture which appeared as thickets was sold to become a relocated housing construction site. The development pattern of the relocated housing environment is in the form of a comb lined up on the edge of the hilly foot connected by the main neighborhood road. In the next few years, the area between the relocated housing environment and the hills developed a $\mathrm{C}$ excavation business. See the Neuheun area spatial process scheme below 


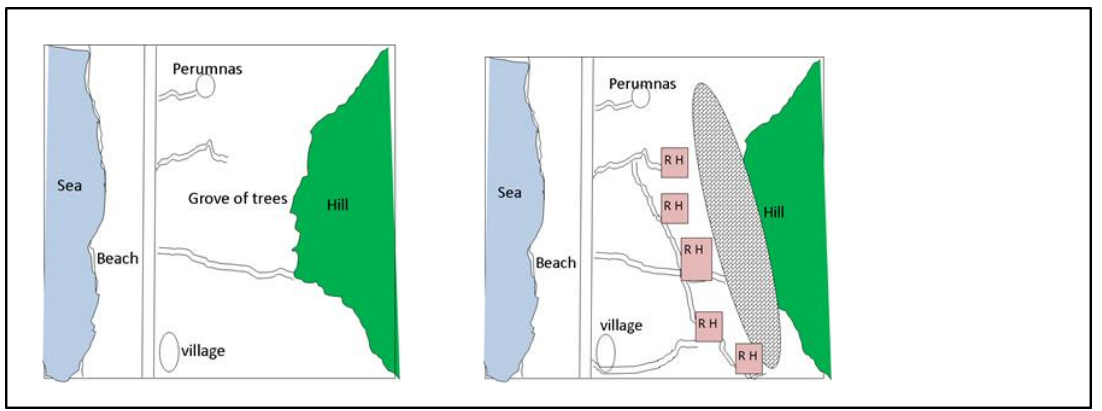

Figure 4: Schematic of the Neuheun area spatial process before the tsunami and post-residential relocation housing, 2020, drawing. Source: analysis.

Thus, it can be seen that the relocated housing environment becomes a barrier between the area under the hills and the hilly area. Based on the above conditions, the environmental impact of relocation housing on area systems is related to two things:

1. The movement paths of the people and animals are disturbed because of the housing layout pattern which gives the impression of fencing the hills. As a result, livestock are driven through the outer ring road of the housing estate, so that the route becomes longer and sometimes makes it difficult for people and livestock. However, there are cattle that cross the residential area, some even forage in the housing. This has an impact on disruption of environmental road traffic, damaging grasslands and green plants in the environment, spreading dirt on the roads. If it is related to the spatial behavior theory (Altman, 1984), the habit of walking in a place will be recorded in the memory of every living thing, including animals that will recognize their habitat and form their path of movement;

2. The housing outer ring road is also utilized by the C-excavation route which makes it easier to penetrate the hills around the housing. The $C$ excavation business carried out by the local community is an opportunity to improve the community's economy on their own land and with a license. This will happen if access is already open to natural resources. According to Hornby and Jones (1991), settlements that are close to natural resources will contribute to these natural changes, to increase their welfare. Uncontrolled mining operations have caused damage to land cover and the hilly slope topography is getting steeper. The conditions in Neuheun Hills are adjacent to the settlement, seen that the cover is very much reduced and the slope topographical is getting steeper. This has damaged the flora resources needed by livestock, and the hillside area becomes vulnerable to rock slide disasters and floods of rain from the hills that threaten the relocated housing environment. See the figure below

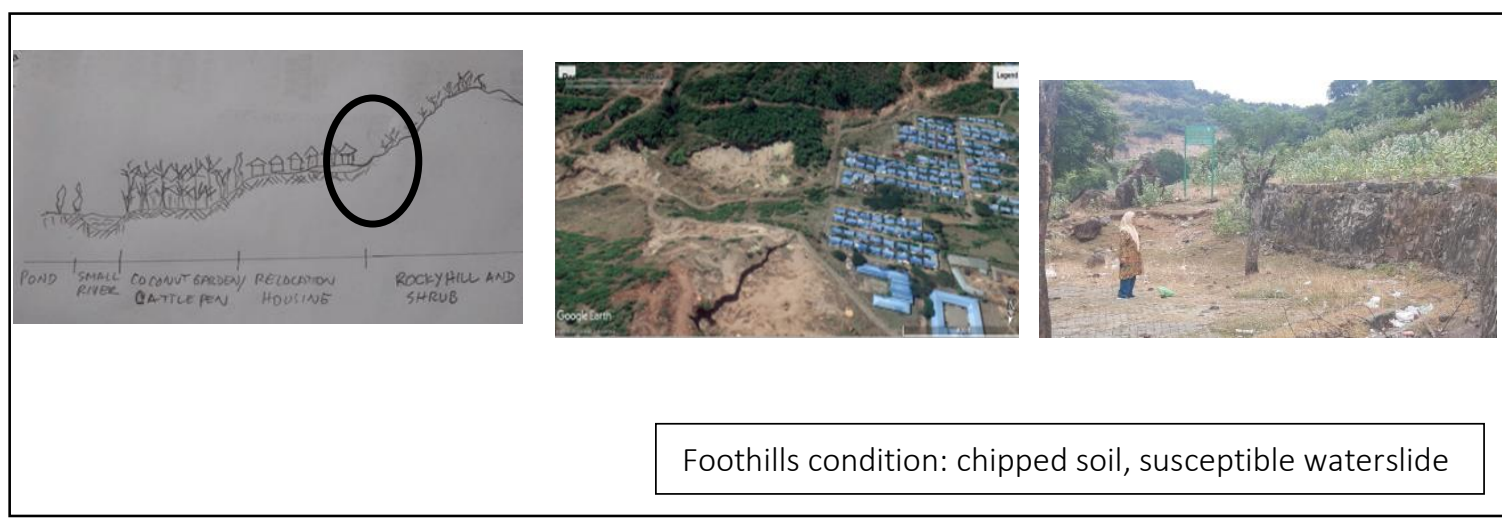

Figure 5: Disaster-prone position cuts, hilly cliff edge conditions, 2020, photo. Source: analysis.

The impact of the existence of the relocated housing environment shows changes in the systems in the area environment widely. This affects the behavior patterns of the community in the area and ultimately has a negative impact on the relocated housing environment itself. In the flow diagram, the system dynamics in the relocation housing environment can be seen as shown below 


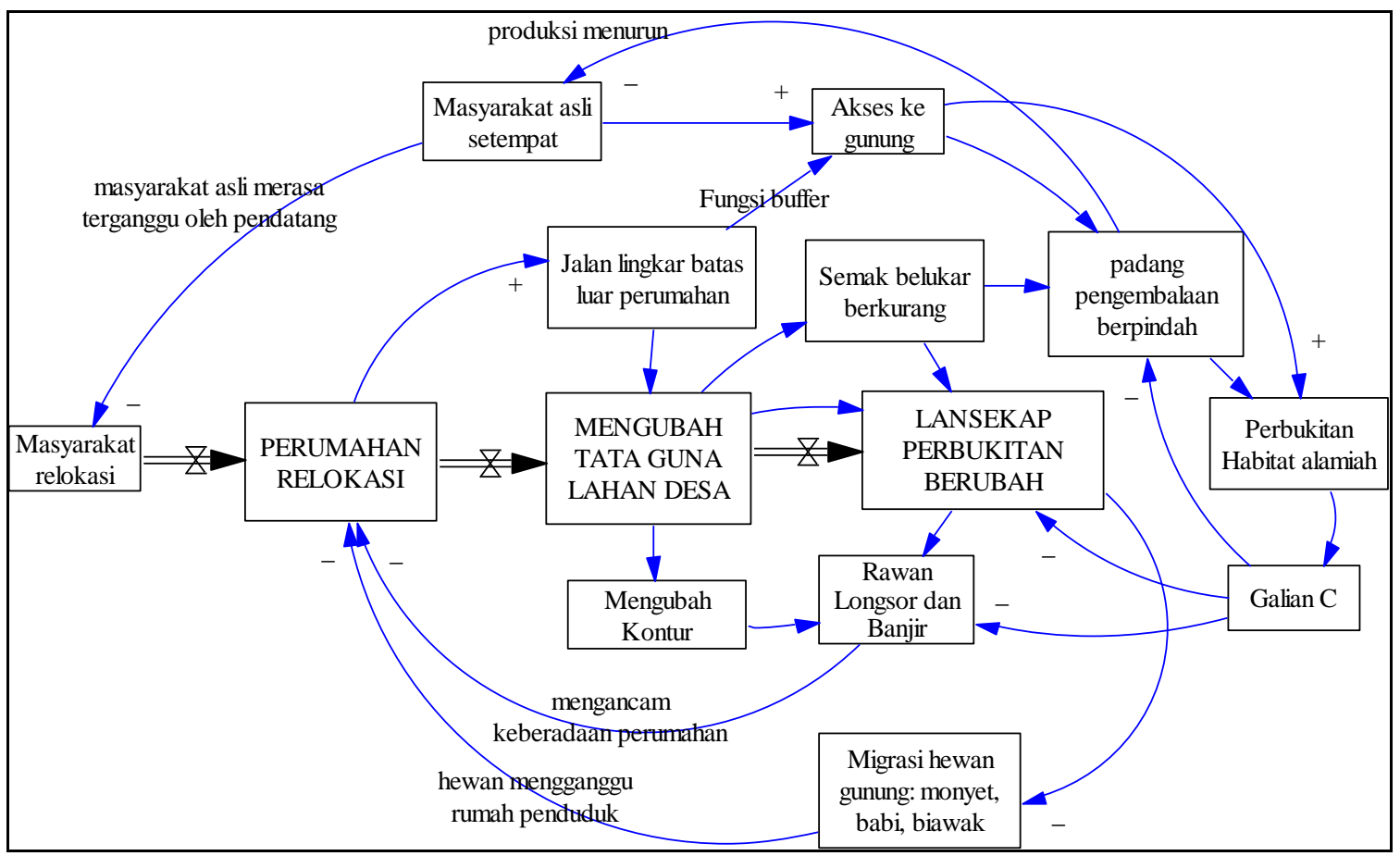

Figure 6: Dynamic system diagram in Cinta Kasih residential relocated environment, 2020, drawing. Source: analysis.

Changes in landscape due to the emergence of relocated housing have disrupted the regional spatial system. Relocated housing and mining operations $C$ is a barrier to the relationship between the community and their natural environment. Diagrammatically as follows

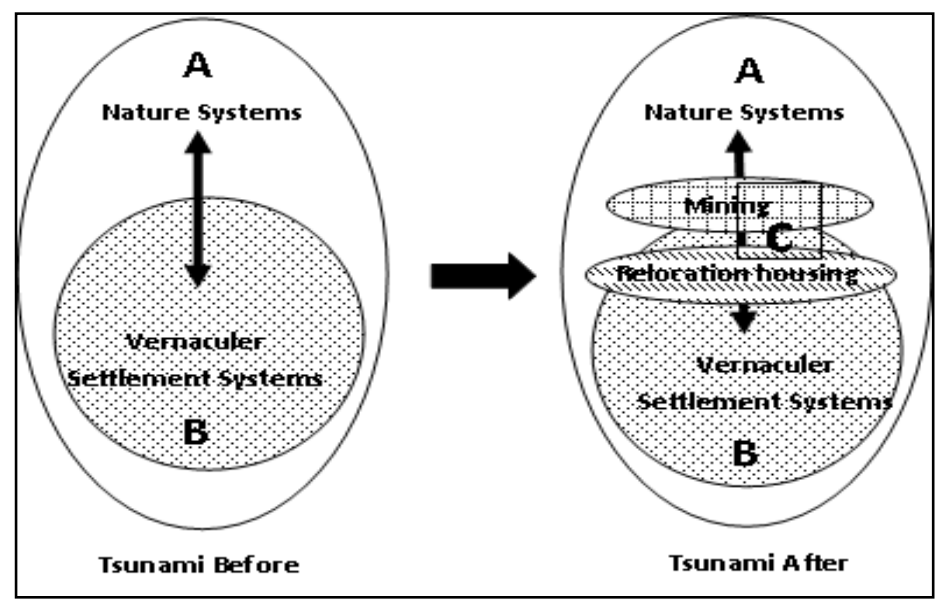

Figure 6: The concept of space in the Neuheun Village Space concept scheme, 2020, graphic. Source: analysis.

By looking at the regional spatial concept scheme that occurred after the tsunami, the existence of relocated housing and mining activities formed a spatial system in space for the village area, whose existence was not contextual. The residents of relocated housing are people with various backgrounds, that's why they have very different habit patterns from local communities. The economic activities of local communities that cross the inside of the relocated housing environment can disturb the comfort of the residents of the relocated housing. On the other hand, the existence of the relocation housing environment becomes a "disturbance" for the behavior of the home range of the community and livestock. This can lead to disintegration between 
communities which will harm the area's sustainability system. According to Horton (1989), social conflict will easily occur when the inequality of life and patterns of living habits in a residential environment is different.

However, the presence of immigrants has also opened up perspectives related to a variety of community economic activities beyond those based on land. Local people are starting to be interested in urban work which is mostly done by these migrant residents. According to information from the head of Neuheun village, many local residents who work in the city have been brought in by migrants. Togetherness and equality of work that have begun to form between immigrant and local communities can gradually become the capital for the sustainability of life together in the Neuheun Village.

\section{Conclusion}

The current existence of Relocation Housing seems to be a disturbance to the harmonious relationship between the Neuheun village area system and its natural environment system. The impact that occurs:

1. Changing pasture, because the location has changed functions. This has a negative impact on the movement pattern of local economic activities in the hills;

2. Excavation activity $\mathrm{C}$ causes damage to the natural system on the hill which has an impact on new grazing areas, and also changes in the landscape causing the area to be prone to landslides and floods;

3. Changes and degradation of the hillside landscape also causes animal migration to the residential environment which disrupts land crops.

Suggestions for the sustainability of the systems in the relocated housing area are maintaining the existence of the physical condition of the area between the relocation housing environment and the hills that can function double, both as a buffer zone and as grazing land and eliminating these community mining activities. This requires public awareness for the environmental sustainability of the area in general.

\section{Acknowledgments}

This paper is part of the Head Lecturer Research Scheme's research report, PNBP notes for 2020. Thank you to the Syiah Kuala University and Gampong Neuheun community for the information, as well as the students participating in the coastal area planning course Urban and Regional Planning Study Program Department of Architecture and Planning, Faculty of Engineering, Universitas Syiah Kuala, even semester 2019-2020, which has helped study data activities and make the necessary maps.

\section{References}

Altman, I. \& Low,S. (1992). Place Attachment, Vol.12 Plenum Press, New York

Brandon,P.S., \& Lombardi,P. (2005) Evaluating Sustainable Development in The Built Environment. Blackwell Science

BRR NAD-Nias. (2008). Enriching the Construction of the Recovery, Annual Report 2007 the Executing Agency for the Rehabilitation and Recosntruction of Aceh and the Nias Island, 2008, ISBN: 978-979-15818-6-8

Doxiadis,C.A. (1968). Ekistics: An Introduction to The Science of Human Settlements. Oxford University Press, New York

Hillier, B. \& Hanson,J. (1984) The Social Logic of Space, Cambridge University Press, New York

Horton, P.B. \& Hunt C.,L. (1989) Sosiologi Ed.VI jilid 2. Erlangga, Jakarta

Hornby,W.F.,\& Jones,M. (1991) An Introduction Settlement Geography. Cambridge University Press.

Muhadjir \& Noeng. (2011) Metodologi Penelitian ed VI. Rake Sarasin,Yogyakarta

Pickett, S.T.A., Cadenasso,M.L., \& Grove,J.M. (2004) Resilient cities: meaning, models, and metaphor for intergrating the ecological, socio-economi, and planning realms. Landscape and Urban Planning 69 (2004) 369-384

Pike, A., Dawley, S., \& Tomaney, J. (2010) Resilience, adaptation and adaptability. Cambridge Journal of Regions, Economic and Society, 1-12

Rapoport, Amos (1983). Environmental Quality, Metropolitan Areas and Tradisional Settlements. Jurnal HABITAT INTL., Vol.7. No.3/4.pp.37-63,1983. Pergamon Press Ltd. England. 
Schulz, Christian Norberg (1984) Genius Loci, Toward A Phenomenology of Architecture. Rizolli, New York

Smith, K., \& Petley, D.N. (2009) Environment Hazards: Asseng Risk and Reducing Disaster (Fifth ed). Routledge, London

Wulandari, E., Nasution, B., Djamaluddin, M., Sabila,F. (2020a) Proses Tumbuh Kembang Permukiman Perdesaan Pantai-Muara Sungai di Pesisir Barat Aceh dan Adaptasi Berkelanjutannya. Kasus: Kawasan Perdesaan Geulanggang Batee, kabupaten Aceh Barat Daya. Jurnal Arsitektur Zonasi. Vol3- Nomor 3- Oktober 2020. P-ISSN 2621-1610 eISSN 2620-9934. Doi.org/10.175/509/jaz.v3i3.27873

Wulandari, E., A Fahmi, A., Evalina, Z., \& Myna, A. (2020b) The Effect of morphology of posttsunami coastal physiography on sustainability system of relocation settlement. Case Study: Gampong Saney, Lhoong sub-district, Aceh Besar regency. IOP Conf.Series: Earth and Environmental Science 452 (2020) 012117 doi: 10.1088/1755-1315/452/1/012117

Wulandari, E., Soetomo,S.,Syahbana, J.A., \& Manaf, A. (2017) The Ecology Character of Banda Aceh City in The $17^{\text {th }}$ Century. Journal of Islamic Architecture 4(3) June 2017. P-ISSN: 2086-2636 E-ISSN: 2356-4644. DOI http://dx.doi.org/10.18860/jia.v4i3.38722

Yunus, Hari Sabari. (2010) Metoda Penelitian Wilayah Kontemporer. Pustaka Pelajar. Yogyakarta

Zakaria, Z. (2004) Stabilisasi dan Rancang Bangun Lereng Terpadu, salah satu usulan untuk penanganan masalah longsor. from: Permasalahan, kebijakan dan Penanggulangan Bencana Longsor di Indonesia. Editor: Naryanto,Heru Sri dkk diterbitkan oleh: P3-TPSLK BPPT dan HSF.ISBN: 979-8801-22-9

https://www.theguardian.com/cities/2014/jan/27/banda-aceh-community-spirit-peace-indonesiatsunam 